PREGLEDNI RAD

UDK: 005.334

Izv. prof. dr. sc. Danijela Miloš Sprčić*

Leon Jakirlić, mag. oec.**

\title{
UPRAVLJANJE REPUTACIJSKIM RIZIKOM KORIŠTENJEM MODELA INTEGRIRANOG UPRAVLJANJA RIZICIMA
}

\author{
MANAGING REPUTATIONAL RISK THROUGH \\ INTEGRATED RISK MANAGEMENT MODEL
}

\begin{abstract}
SAŽETAK: Reputacija je odraz načina na koji različite interesne skupine vide neku kompaniju. Rizik gubitka reputacije najčešće nastaje kao posljedica nastupanja nepovoljnih događaja koji proizlaze iz izloženosti kompanije različitim strateškim, operativnim i financijskim rizicima. Gubitak reputacije dokazano uzrokuje pad financijskih performansi kompanije s često dugoročnim posljedicama. Upravo zbog velikog utjecaja događaja s negativnim posljedicama na reputaciju, u ovome radu naglašava se značaj „unaprednog“ prepoznavanja i učinkovitoga upravljanja faktorima rizika iz eksternoga i internoga okruženja organizacije. Temeljni cilj rada jest iznijeti prijedlog modela upravljanja reputacijskim rizikom kroz sustav integriranoga upravljanja rizicima kojime se identificira, kvantificira i upravlja svim poslovnim rizicima. U radu se analizira anticipativni model upravljanja reputacijskim rizikom, što znači da se mogućim čimbenicima rizika upravlja unaprijed kako bi ih se na vrijeme spriječilo odnosno kako bi se smanjila vjerojatnost njihova nastupanja te smanjila značajnost za ciljeve organizacije.
\end{abstract}

KLJUČNE RIJEČI: reputacija, vrijednost poduzeća, reputacijski rizik, integrirano upravljanje rizicima.

ABSTRACT: Reputation is a reflection of how different interest groups see a company. The risk of loss of reputation is, most often, the result of adverse events that arise from the company exposure to various strategic, operational and financial risks. Loss of reputation has proven to cause the reduction of company's financial performance with the long-term consequences. Due to the fact that events with negative consequences usually have significant impact on the company's reputation, this paper emphasizes the importance of advanced identification and effective management of risk factors from the external and internal environment of the organization. The fundamental objective of the paper is to pro-

Izv. prof. dr. sc. Danijela Miloš Sprčić, Katedra za Ekonomiku poduzeća, Ekonomski fakultet - Zagreb, Trg J.F. Kennedyja 6, 10000 Zagreb, Hrvatska, Email: dmilos@efzg.hr

** Leon Jakirlić, mag. oec., Pliva Hrvatska d.o.o., Prilaz baruna Filipovića 25, 10000 Zagreb, Hrvatska, Email: leonjakirlic@gmail.com 
pose a model of reputational risk management by using integrated risk management system that identifies, quantifies and manages all business risks. The paper analyses preventive anticipation approach to managing reputational risk, in contrast to reactive approach, which means that the drivers of reputational risks are managed in advance to prevent them on time, or to reduce their likelihood of occurrence and/or diminish their relevance to the organization's goals.

KEY WORDS: reputation, enterprise value, reputation risk, integrated risk management.

\section{UVODNA RAZMATRANJA}

Warren Buffett jedan je od najuspješnijih investitora na svijetu. Njegova investicijska strategija temelji se na ulaganju u neopravdano podcijenjene dionice kompanija čija fundamentalna vrijednost nije prepoznata od strane drugih investitora. Prije svega, zanimaju ga kompanije koje imaju snažan profitni potencijal održiv u dugom roku, što je jedino moguće ostvariti uz pretpostavku kvalitete poslovanja, jasno postavljenih poslovnih ciljeva i strategije njihovoga ostvarenja, ali i učinkovitoga upravljanja internim i eksternim poslovnim rizicima koji bi mogli ugroziti ostvarenje ciljeva. Čini se da njegova filozofija ulaganja donosi izvrsne rezultate, obzirom da je prema listi časopisa Forbes već dugi niz godina jedan od najbogatijih ljudi u SAD-u, ali i cijelome svijetu. Warren Buffett nije poznat samo po svom velikom bogatstvu i iznimnim filantropskim aktivnostima već i po svojoj promišljenosti i mudrosti pa je tako prozvan u javnosti „Mudracem iz Omahe“. Jedna od njegovih najpoznatijih izjava kako je ,potrebno 20 godina da se izgradi reputacija, a samo 5 minuta da se ona uništ $i$ “ daje naslutiti koliko je za njega reputacija važna te koliko pozornosti joj posvećuje prilikom upravljanja svojim poslovnim portfeljem, ali i svojim vlastitim ugledom. Iz navedene izjave može se zaključiti kako je jedan od životnih uzora Warrena Buffetta vjerojatno veliki američki državnik, filozof, izumitelj, fizičar, diplomat, ekonomist i pisac Benjamin Franklin, koji je još u 18. stoljeću izjavio kako je „potrebno mnogo dobrih dijela da se izgradi dobra reputacija, a samo jedno loše da se ona izgubi“.

Navedene mudre izreke primjenljive su, kako za osobnu, tako i za poslovnu reputaciju. Ovaj rad bavi se poslovnom reputacijom te promatra reputaciju organizacije kao „rizik od rizika“. Reputacijski rizik potencijalno nastaje kao posljedica svih drugih strateških, operativnih i financijskih rizika kojima je organizacija izložena. Gubitak reputacije uslijed nastanka nekog nepovoljnog događaja dokazano uzrokuje pad financijskih performansi kompanije s često dugoročnim posljedicama. Jedan od ciljeva ovoga rada je analizirati recentna i relevantna istraživanja na temu reputacijskoga rizika te ih kritički prikazati i sintetizirati njihove zaključke radi prikazivanja važnosti poslovne reputacije kao faktora rizika i njezinoga utjecaja na vrijednost organizacija. Ipak, temeljni cilj rada jest iznijeti prijedlog modela upravljanja reputacijskim rizikom kroz sustav integriranog upravljanja rizicima (engl. Enterprise Risk Management - ERM) kojime se identificira, kvantificira i upravlja svim poslovnim rizicima. $U$ radu se iznose argumenti koji govore u prilog ERM sustavu kao učinkovitome modelu ,unaprednog“ upravljanja reputacijskim rizikom kroz pravodobno identificiranje i procjenu onih rizičnih čimbenika čiji nastup bi mogao imati štetan utjecaj na reputaciju organizacije. Radi se o anticipativnom, a ne reaktivnom pristupu reputacijskome riziku, što znači da se čimbenicima mogućega reputacijskog rizika upravlja 
unaprijed kako bi ih se na vrijeme spriječilo odnosno kako bi se smanjila vjerojatnost njihova nastupanja odnosno smanjila značajnost za ciljeve organizacije. Jednom kada se događaji s negativnim posljedicama za reputaciju dogode, tada se više ne govori o upravljanju rizicima već o kriznom menadžmentu, što nije područje ovoga rada.

Prvi dio rada bavi se konceptom reputacije te istražuje dostupnu literaturu s ciljem pružanja okvira i definicije reputacije. Također, promatra se veza između reputacije i vrijednosti organizacije, koja je od ključne važnosti za opravdanost upravljanja reputacijskim rizikom. Drugi dio rada promatra reputaciju kao rizik uslijed izloženosti mnogim nepovoljnim događajima. Analiziraju se metode upravljanja reputacijskim rizicima, a posebna pozornost posvećuje se sustavu integriranog upravljanja rizicima. Na kraju rada autori iznose prijedlog modela upravljanja reputacijskim rizikom preko sustava integriranog upravljanja rizicima, što je, osim kritičkoga pregleda relevantne literature, temeljni doprinos ovoga rada.

\section{UTJECAJ PERCEPCIJE DIONIKA NA POSLOVNU REPUTACIJU I VRIJEDNOST KOMPANIJE}

\subsection{Definiranje poslovne reputacije}

Brojna istraživanja dala su svoj doprinos pokušaju definiranja pojma poslovne reputacije, no općeniti konsenzus i dalje ne postoji. Prema Larkin (2003.) reputacija u poslovnom kontekstu temeljena je na percepciji karakteristika, performansi i ponašanja kompanije, njenih zaposlenika i svih drugih dionika odnosno nositelja interesa (engl. stakeholders). U biti reputacija je odraz načina na koji različite interesne skupine vide neku kompaniju. Reputacija utječe na odabir proizvoda i usluga koje kupujemo, investicija u koje se upuštamo te u konačnici karijere za koju se odlučujemo. ${ }^{1}$ Gotsi i Wilson (2001.) identificiraju temeljne karakteristike reputacije te zaključuju da se radi o dinamičnom konceptu za kojega je potrebno vrijeme da se izgradi i održava, a koji istovremeno ovisi o svakodnevnoj percepciji koju ljudi stvaraju o nekoj organizaciji. Također, poslovna reputacija u velikoj mjeri određuje položaj kompanije u odnosu na konkurente, a ovisi i o samim dionicima kompanije, koji mogu imati različite percepcije uslijed ekonomskih, socijalnih ili osobnih specifičnosti. ${ }^{2} \mathrm{U}$ sličnom kontekstu Hutt (2016.) tvrdi kako je ,poslovna reputacija kompleksan koncept koji opisuje koliko pozitivno ili negativno ključni dionici, poput zaposlenika, klijenata, investitora, medija, dobavljača i financijskih analitičara percipiraju neku kompaniju." Također, ističe kako je reputacija, uz ostalu neopipljivu imovinu poput patenata, inovacija, ljudskog kapitala, odnosa s klijentima i sl., središnji element konkurentnosti i profitabilnosti kompanije. ${ }^{3}$ Definicije poslovne reputacije tipično uključuju ,koncept višedimenzionalne društvene konstrukcije koja uključuje agregirane percepcije ključnih dionika kompanije vezane uz financijske i nefinancijske aspekte promatrane kompanije. "“4

Larkin, J. (2003), Strategic Reputation Risk Management, Palgrave Macmillan, New York.

Gotsi, M., Wilson, A. M. (2001), Corporate reputation: seeking a definition, Corporate Communications: An International Journal, Vol. 6 Issue: 1, pp. 24-30.

Hutt, R. W. (2016), Reputation on the line: the Starbucks cases, Journal of Business Strategy, Vol. 37 Issue: 1, pp. 19-26.

$4 \quad$ Gatzert, N., Schmit, J. (2016), Supporting strategic success through enterprise-wide reputation risk management, The Journal of Risk Finance, Vol. 17 Issue: 1, pp. 26-45. 
Louisot i Gaillard (2006.) su ustanovili da je reputacija, kao društvena konstrukcija koja počiva na mišljenjima i percepcijama ljudi, postala značajan ekonomski faktor. Iako reputacija predstavlja nematerijalnu imovinu kompanije, kojoj se prema ustaljenim računovodstvenim standardima ne dodjeljuje nikakva realna vrijednost, ona je zasigurno jedan od najvažnijih i najdragocjenijih oblika nematerijalne imovine poduzeća. ${ }^{5}$ Fombrun i van Riel (1997.) definiraju reputaciju kao „kolektivnu reprezentaciju prošlih akcija i rezultata neke kompanije koja opisuje njenu sposobnost pružanja vrijednosnih ishoda prema dionicima. Reputacija je mjerilo relativne pozicije neke kompanije, kako interno, prema zaposlenicima, tako i eksterno, prema drugim dionicima interesa u okruženju. “6 Prema Firesteinu (2006.) reputacija je najjača determinanta održivosti kompanije. Kada je reputacija organizacije uništena, njen oporavak je težak, dugotrajan i neizvjestan. Stoga je svaki faktor rizika koji može negativno utjecati za reputaciju stvarna prijetnja opstanku organizacije. ${ }^{7}$

Zbog utjecaja društvenih mreža i suvremenih medija, obilje informacija koje se brzo šire dostupno je u svakome trenutku. Uz to, utjecaj globalizacije implicira veliki broj konkurentskih proizvoda i usluga. Kada nemaju vlastito prethodno iskustvo, kupci su skloni odabiru onih proizvoda čije kompanije imaju dobru poslovnu reputaciju. Zbog toga bi sve organizacije trebale raditi na dugoročnoj izgradnji pozitivne reputacije. ${ }^{8}$ Resnick (2004.) tvrdi kako, unatoč povećanom medijskom fokusu prema poslovnoj reputaciji uslijed velikih korporativnih skandala, većina menadžera i dalje zanemaruje aktivnosti koje štite kompaniju od neočekivanih udara na reputaciju. Sve dok menadžeri ne budu primjenjivali jednako stroge kriterije zaštite od reputacijskog rizika, kao što to čine za financijske, operativne ili strateške rizike, reputacija njihovih kompanija bit će u opasnosti. ${ }^{9}$ Nažalost, ljudi i organizacije o reputaciji ozbiljno razmišljaju samo u teškim i neizvjesnim vremenima ili tek nakon nastanka nekog incidenta, dok u vremenima rasta i blagostanja pretendiraju zaboraviti na važnost reputacije. Jedno od najvažnijih pravila upravljanja poslovnom reputacijom je upravo potreba za konstantnom zaštitom i nadzorom. Upravo zbog globalne prirode današnjega poslovanja i brzine širenja informacija, organizacije moraju biti pod neprestanim oprezom. ${ }^{10}$

Prema Scott i Walsham (2005.), u suvremenim ekonomijama temeljenim na znanju kompanije se suočavaju s izazovom definiranja svoje reputacije i odnosa s dionicima u uvjetima stalnih promjena okvira društvene odgovornosti i tolerancije rizika. U takvim uvjetima, vrijednost reputacije sve više raste i dolazi do izražaja, jer tehnički sustavi i poslovni procesi postaju sve više standardizirani i sve ih je lakše replicirati, omogućujući da ekspertiza i dobra reputacija postanu temelj strateške diferencijacije. ${ }^{11} \mathrm{~S}$ druge strane, učinkovito

Louisot J. P., Gaultier-Gaillard, S. (2006), Risks to Reputation: A Global Approach, The Geneva Papers 2006, 31, (425-445).

6 Fombrun, C., van Riel, C. (1997), The reputational landscape: a convergence of research and practice, Corporate Reputation Review, Vol. 1 Nos 1/2, pp. 1-16.

$7 \quad$ Firestein, P. J. (2006), Building and protecting corporate reputation, Strategy \& Leadership, Vol. 34 Issue: 4, pp. 25-31.

8 Eckert, C. (2017), Corporate reputation and reputation risk: Definition and measurement from a risk management perspective, The Journal of Risk Finance, Vol. 18 Issue: 2, pp. 145-158.

9 Resnick, J. T. (2004), Corporate reputation: Managing corporate reputation - applying rigorous measures to a key asset, Journal of Business Strategy, Vol. 25 Issue: 6, pp. 30-38.

10 Alsop, R. J. (2004), Corporate reputation: Anything but superficial - the deep but fragile nature of corporate reputation, Journal of Business Strategy, Vol. 25 Issue: 6, pp. 21-29.

11 Scott, S. V., Walsham, G. (2005), Reconceptualizing and Managing Reputation Risk in the Knowledge Economy: Toward Reputable Action, Organization Science, Vol. 16, No. 3 (May - Jun. 2005), pp. 308-322. 
upravljanje onim rizicima koji mogu naštetiti reputaciji kompanije može donijeti mnoge druge, naizgled neočekivane koristi za cjelokupno poslovanje. U tome kontekstu Hirsch (2015.) ističe da je ,sposobnost kompanije da sustavno nadzire i upravlja prijetnjama iz kojih može proizaći reputacijski rizik iznimno moćan menadžerski alat koji omogućuje pravovremeno sprječavanje kriza uzrokovanih negativnim promjenama percepcije javnosti i dionika." Uz sprječavanje kriza, treba naglasiti da učinkovito upravljanje reputacijskim rizicima omogućuje identificiranje prilika u kojima bi kompanija nekom reakcijom na reputacijski rizik o sebi stvorila dojam progresivnog lidera te na taj način ostvarila reputacijsku prednost u odnosu na konkurente. ${ }^{12}$

Temeljem svega navedenoga, može se zaključiti kako je dobra reputacija nematerijalna imovina velike vrijednosti za organizaciju. ${ }^{13}$ Činjenicu da pozitivna reputacija doprinosi vrijednosti suvišno je preispitivati, no precizno kvantificirati točnu vrijednost reputacije te njezin doprinos ukupnoj vrijednosti organizacije nije jednostavan zadatak. Suvremena istraživanja govore kako se vrijednost reputacije može samo aproksimirati, pomoću drugih čimbenika vrijednosti kompanije. Stoga će se u nastavku rada pokušati razmotriti veza između reputacije i vrijednosti.

\subsection{Utjecaj reputacije na vrijednost kompanije}

Dobra reputacija snažno utječe na privlačenje investitora, talentiranih ljudskih potencijala, ali i pozornosti klijenata i kupaca koji su spremni platiti više za proizvod ili uslugu kompanije koja ima dobru reputaciju. U stvaranju dobre reputacije i pozitivne percepcije svih interesnih skupina neke kompanije važnu ulogu igraju Odnosi s javnošću te Odnosi s investitorima, što je posebno relevantno za poduzeća s kotacijom na burzi koja moraju zadovoljiti propisanim razinama transparentnosti poslovanja te periodično izvještavati javnost o svojim poslovnim aktivnostima i financijskim rezultatima. Promatramo li poslovno okruženje, tada s jedne strane imamo kompanije i informacije koje one proizvode. S druge strane, imamo analitičare tržišta kapitala koji nude svoje znanje i mišljenja o kompanijama i različitim industrijama, kao i medije koji aktivno prate aktivnosti tržišta kapitala i događanja u poslovnome svijetu te ih prenose do zainteresirane javnosti. U istome okruženju nalaze se i brojne interesne skupine kao što su zaposlenici te dobavljači i kupci sa svojim zahtjevima i aktivnostima. Svi oni zajednički imaju značajan utjecaj na investitore, a onda i na formiranje tržišne vrijednosti neke kompanije. Bez obzira o kojim se investitorima radi, individualnim ili institucionalnim, svi oni ovise o informacijama temeljem kojih donose investicijske odluke. ${ }^{14} \mathrm{U}$ tome kontekstu, informacije o nepovoljnim događajima koji negativno utječu na reputaciju neke kompanije često uzrokuju gubitak tržišne vrijednosti kompanije koji je veći od računovodstvenoga gubitka nastaloga nepoželjnog događaja, a koji se mjeri kroz pad

12 Hirsch, P. B. (2015), Sacred cows and the known unknowns, Journal of Business Strategy, Vol. 36 Issue: 6, pp. 54-58.

13 Murray, K. (2004), Reputation - Managing the single greatest risk facing business today, Journal of Communication Management, Vol. 8 Issue: 2, pp. 142-149.

14 Ryan, T. M. i Jacobs, C. A. (2004) Using Investor Relations to Maximize Equity Valuation. Wiley finance series, str. 54. 
vrijednosti dionica kompanije. Gubici povezani s gubitkom reputacije obično donose i pad očekivanih prihoda kompanije te porast troškova financiranja. ${ }^{15}$

Stoga je za stvaranje pozitivne reputacije kompanije važno na primjeren način usmjeravati poslovne i financijske informacije prema zainteresiranoj javnosti, za što se brinu specijalisti za Odnose s javnošću te Odnose s investitorima. ${ }^{16}$ Iz slike 1. evidentan je utjecaj percepcije investitora, a onda i reputacije neke kompanije na njezinu tržišnu vrijednost. Za formiranje tržišne vrijednosti kompanije temeljnu ulogu imaju fundamentalni pokazatelji poput očekivanih zarada i novčanih tokova kompanije, kretanje cjelokupne pripadajuće industrije, ali i očekivanja investitora. Tržišna vrijednost određena je ponudom i potražnjom za dionicama neke kompanije te nije uvijek usklađena s fundamentalnom vrijednošću koja se temelji na očekivanim slobodnim novčanim tokovima diskontiranim na sadašnju vrijednost odnosno koja je dobivena matematičkim proračunom uz korištenje prikladnih kvantitativnih metoda vrednovanja. Tako dionice neke kompanije mogu biti precijenjene ili podcijenjene u odnosu na fundamentalnu vrijednost, u ovisnosti o događanjima na tržištu kapitala. Na tržišnu vrijednost kompanije utječe, osim fundamentalne vrijednosti, i mnoštvo drugih čimbenika pa tako i reputacija kompanije te informacije koje dolaze do investitora i ostale zainteresirane javnosti. Ako menadžment želi utjecati na rast vrijednosti kompanije, a time i bogatstva vlasnika, onda osim dobrih poslovnih i investicijskih odluka koje povećavaju novčane tokove kompanije, trebaju utjecati i na stvaranje pozitivne reputacije kompanije održive u dugom roku.

Slika 1. Utjecaj percepcije investitora na tržišnu vrijednost kompanije

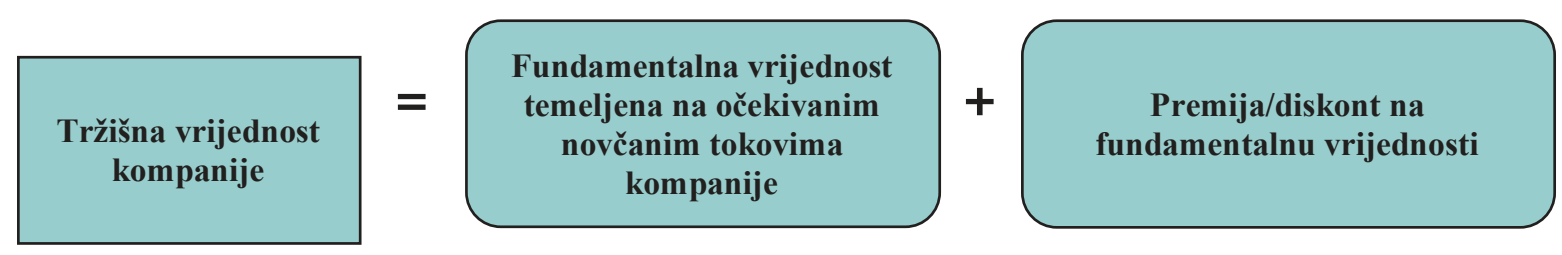

Izvor: Ryan, T. M. i Jacobs, C. A. (2004), Using Investor Relations to Maximize Equity Valuation. Wiley finance series, str. 54.

Gatzert i Schmit (2016.) ističu da postoje brojni empirijski dokazi i zaključci provedenih istraživanja o relevantnosti reputacije za vrijednost kompanije koji potvrđuju da dugoročno ulaganje u stvaranje pozitivne reputacije donosi visoke prinose za vlasnike kompanije. Općenito govoreći, dobra reputacija je u pravilu znak dobre kvalitete proizvoda i usluga koje neka kompanija nudi. Pozitivna reputacija kompanije smatra se nematerijalnom imovinom od strateške važnosti, pošto kompanije koje imaju dobru reputaciju postižu značajne konkurentske prednosti u odnosu na konkurente niže reputacije. Uz to, dobra poslovna reputacija pozitivno utječe na ponašanje pripadnika interesnih skupina, s naglaskom

15 Walter, I. (2013), The value of reputational capital and risk in banking and finance, Banking, Accounting and Finance, Vol. 5, Nos. 1/2, 2013.

16 Miloš Sprčić, Danijela; Bandula, Martina (2010), Utjecaj aktivnosti odnosa s investitorima na trošak kapitala i prognoze financijskih analitičara // Proceedings of the 2nd International Conference "Vallis Aurea" focus on: Regional Development / prof. dr. sc. Branko Katalinić (ur.) Požega: Polytehnic of Požega, Croatia \& DAAAM International Vienna, Austria, 911-922. 
na ponašanju kupaca odnosno potrošača proizvoda i usluga kompanije. Čvrsto utemeljena pozitivna reputacija doprinosi vrijednosti cijele kompanije na način da potiče trošenje $i$ generira namjeru kupovine te stvara lojalnost i povjerenje kupaca. ${ }^{17}$

Na druge interesne skupine pozitivna reputacija ima sličan utjecaj. Na primjer, dobavljači reagiraju na pozitivnu reputaciju kompanije tako što nude bolje uvjete plaćanja zbog dojma niskog kreditnog rizika. S druge strane, ako investitori imaju pozitivnu percepciju o kompaniji, omogućit će joj lakši pristup kapitalu, niže troškove financiranja te veću fleksibilnost vezanu uz tipove financijskih instrumenata. Također, kompanije s dobrom reputacijom privući će kvalitetnije zaposlenike te time ostvariti dodatne konkurentske prednosti. ${ }^{18}$

\section{REPUTACIJA KAO RIZIK}

Skoro svaka odluka donesena u nekoj kompaniji, u slučaju da nešto pođe po zlu, ima potencijal da preraste u incident koji može uništiti reputaciju kompanije. Pogrešni koraci mogu vrlo lako migrirati s jednoga proizvoda na cijelu proizvodnu liniju i negativno utjecati na sve brendove te cjelokupni imidž kompanije, u slučaju da se loše vijesti dugo zadrže u medijima ili na društvenim mrežama. ${ }^{19}$ Period u kojemu su kompanije smatrane reputacijskim „utvrdama“ je završen; živimo u vremenu u kojemu su nadzor i prosudba od strane medija, općeg društva, regulatora i drugih interesnih skupina svakodnevni i intenzivni. Razvoj komunikacijskih tehnologija i široka dostupnost informacija su katalizatori stvaranja percepcije i svijesti općeg društva. Mediji, neprofitne organizacije i druge interesne skupine mogu vrlo lako otkriti loše ponašanje i učinkovito proširiti informacije o mogućim poslovnim nedjelima. ${ }^{20}$ Upravo iz razloga velike zaraznosti negativnog utjecaja na reputaciju, u ovome radu naglašava se značaj ,unaprednog“" prepoznavanja i učinkovitog upravljanja faktorima rizika iz eksternog i internog okruženja organizacije, kako se događaji s negativnim posljedicama na reputaciju ne bi niti dogodili. Jednom kada se dogode, tada više ne govorimo o upravljanju rizicima već o kriznome menadžmentu.

Gatzert i Schmit (2016.) definiraju reputaciju kao „,rizik od rizika“, što znači da se generira iz drugih izvora varijabilnosti. ${ }^{21}$ Culp (2002.) povezuje reputaciju uz financijske i operativne rizike kojima su izložene sve organizacije, na način da se gubitak dobrog imena odnosno reputacije transformira u smanjenje prihoda, povećanje troškova odnosno pad broja kupaca te posljedično u pad tržišnoga udjela te smanjenje proizvodnje. Sve navedene transformacije reputacijskoga rizika imaju negativan učinak na financijsku uspješnost i produktivnost kompanije. Reputacijski rizici mogu nastati kada organizacija nemarno posluje

17 Gatzert, N., Schmit, J. (2016), Supporting strategic success through enterprise-wide reputation risk management, The Journal of Risk Finance, Vol. 17 Issue: 1, pp. 26-45.

Ibid., str. 27.

Hutt, R. W. (2016), Reputation on the line: the Starbucks cases, Journal of Business Strategy, Vol. 37 Issue: 1 , pp. 19-26.

20 Firestein, P. J. (2006), Building and protecting corporate reputation, Strategy \& Leadership, Vol. 34 Issue: 4, pp. 25-31.

21 Gatzert, N., Schmit, J. (2016), Supporting strategic success through enterprise-wide reputation risk management, The Journal of Risk Finance, Vol. 17 Issue: 1, pp. 26-45. 
ili je percipirana kao da nemarno posluje. Reputacijski rizici također mogu nastati kao posljedica lošeg upravljanja Odnosima s javnošću u kontekstu nastanka eksternih kriza, bez obzira bile one uzrokovane od strane organizacije ili ne. Na primjer, pad zrakoplova uzrokovan lošim vremenskim uvjetima može imati vrlo negativne posljedice na zračnu kompaniju, ali i na proizvođača zrakoplova, iako one možda nisu izravno uzrokovale incident. Reputacijski rizik također može nastati kada organizacija jednostavno ne izvrši svoje obveze. Kada na primjer proizvođač IT opreme ne poštuje rokove garancije definirane jamstvenim listom, ili kada osiguravajuće društvo ne želi isplatiti odštete u slučaju nastanka štetnog događaja pokrivenog premijom osiguranja, tada će zasigurno brzo izgubiti na reputaciji i smanjit će im se baza klijenata. ${ }^{22}$

Američka središnja banka (engl. Federal Reserve System) u svome Okviru supervizije velikih financijskih institucija definira reputacijski rizik kao ,potencijal da negativni publicitet vezan uz poslovnu praksu neke institucije, istinit ili ne, uzrokuje smanjenje baze klijenata, pad prihoda, ili skupe sudske parnice." ${ }^{23}$ Prema Basel II okviru supervizije bankarskoga sektora, reputacijski rizik može se definirati kao „rizik koji proizlazi iz negativne percepcije od strane klijenata, partnera, dioničara, investitora, vjerovnika, financijskih analitičara, regulatora ili drugih relevantnih strana koje mogu negativno utjecati na mogućnost banke da zadrži postojeće, ili uspostavi nove poslovne odnose te da ima kontinuirani pristup izvorima financiranja. Reputacijski rizik je višedimenzionalan i odražava percepciju drugih sudionika na tržištu. Dodatno, reputacijski rizik postoji kroz cijelu organizaciju, a izloženost njemu je u suštini funkcija adekvatnosti bančinih internih procesa upravljanja rizicima. Također, reputacijski rizik je i funkcija sposobnosti i učinkovitosti menadžmenta u reagiranju na eksterne utjecaje vezane uz bančine transakcije. ${ }^{24}$ Ova definicija obuhvaća svu dubinu i složenost reputacijskih rizika te ukazuje na nužnost učinkovitog upravljanja internim procesima organizacije, ali i važnost identificiranja eksternih čimbenika rizika. S druge strane, Eckert (2017.) analizom dostupne literature i istraživanja zaključuje da ne postoji općeprihvaćena metoda mjerenja poslovne reputacije i vezanih rizika. Iako su uglavnom sve prethodne definicije suglasne u promatranju reputacije kao ,rizika od rizika“, različiti autori se usredotočuju na različite aspekte. Iz tog razloga Eckert (2017.) predlaže holistički pristup mjerenja i upravljanja rizikom poslovne reputacije na način da se učinkovito upravlja svim rizicima kojima je kompanija izložena. ${ }^{25}$

22 Culp, L. C. (2002), The Art of Risk Management, John Wiley \& Sons.

23 United States Federal Reserve Board (1997), Framework for risk-focused supervision of large Complex institutions, dostupno na: www.federalreserve.gov/boarddocs/srletters/1997/sr9724a1.pdf (pristupano 15. 9. 2017.).

24 Basel Committee (2009), Enhancements to the Basel II Framework, Basel, dostupno na: www.bis.org/ publ/bcbs157.pdf (pristupano 15. 9. 2017.).

25 Eckert, C. (2017), Corporate reputation and reputation risk: Definition and measurement from a risk management perspective, The Journal of Risk Finance, Vol. 18 Issue: 2, pp. 145-158. 


\section{UPRAVLJANJE REPUTACIJSKIM RIZIKOM}

Reputacijski rizik predstavlja vrstu rizika za poslovanje, radikalno drukčiju od npr. prekida proizvodnje uzrokovanoga požarom, računalnoga kriminala, rizika promjene kamatnih stopa ili deviznih tečajeva te drugih tradicionalnih rizika protiv kojih se organizacije mogu osigurati. U tome smislu, Murray (2004.) ističe da „moć mišljenja prosječnog čovjeka na ulici ima potencijal da uništi poslovanje neke organizacije na način na koji drugi rizici to teško mogu učiniti. “Činjenica je da danas premalo organizacija redovito preispituje svoju reputaciju i uz nju vezane rizike. ${ }^{26}$ Firestein (2006.) smatra reputaciju jednim od najvećih paradoksa korporativnoga upravljanja. Iako nitko ne dovodi u pitanje važnost poslovne reputacije, viši menadžment se rijetko fokusira na nju, kao na recimo neka druga, konkretnija pitanja poput razvoja novih proizvoda, širenja tržišta, prikupljanja kapitala i sl. U tek manjem broju kompanija reputacija je uključena na listu rizika kojima se aktivno upravlja. Jedan od glavnih razloga za takav tretman je činjenica da organizacije ne mogu procijeniti odnos troškova i koristi inicijativa upravljanja reputacijskim rizikom iz razloga što ne mogu precizno odrediti koliko bi koštao utjecaj nekog negativnog događaja koji se još nije dogodio. ${ }^{27}$

Prema Alsop (2004.), da bi upravljanje reputacijom postalo dijelom korporativne kulture, organizacije moraju biti puno više od pasivnog čuvara reputacije. Nema sumnje da glavni izvršni direktor mora odrediti smjer upravljanja reputacijom te na kraju biti odgovoran za nju, no održavanje reputacije je danonoćni posao. Organizacije trebaju odrediti ljude na funkcijama koji će biti primarni čuvari reputacije. Ako žele maksimalizirati vrijednost svojih reputacija, organizacije trebaju upravljanje reputacijskim rizikom učiniti fundamentalnim dijelom svoje organizacijske kulture i sustava vrijednosti. Dodatno, reputacija mora biti srodna s identitetom organizacije, a ne samo imidž koji se promovira manipulirajući odnosima s javnošću. ${ }^{28}$ Scott i Walsham (2005.) sugeriraju „da se uspješno upravljanje reputacijskim rizicima ne može postići jednokratnim ili kratkoročnim rješenjima, već je to postepeno postignuće koje zahtijeva osjetljivost na kontekst, sadržaj i procese. Kapacitet prepoznavanja prilika za poboljšanje reputacije će se puno učinkovitije razviti kao posljedica sistematiziranih i cjelovitih procesa, dizajniranih u svrhu poboljšanja reputacije." 29 Drugi eksperti za reputaciju sugeriraju da je upravljanje reputacijom organizacije primarno uloga i odgovornost glavnog izvršnog direktora, zajedno s drugim članovima uprave, ali i da je reputacija u biti odgovornost svakog zaposlenika. ${ }^{30}$ Upravo iz tog razloga, koncept integriranog upravljanja rizicima (engl. ERM - Enterprise Risk Management) nameće se kao rješenje za učinkovito upravljanje reputacijskim rizikom.

\footnotetext{
26 Murray, K. (2004), Reputation - Managing the single greatest risk facing business today, Journal of Communication Management, Vol. 8 Issue: 2, pp. 142-149.

27 Firestein, P. J. (2006), Building and protecting corporate reputation, Strategy \& Leadership, Vol. 34 Issue: 4, pp. 25-31. Alsop, R. J., (2004), Corporate reputation: Anything but superficial - the deep but fragile nature of corporate reputation, Journal of Business Strategy, Vol. 25 Issue: 6, pp. 21-29.

29 Scott, S. V., Walsham, G. (2005), Reconceptualizing and Managing Reputation Risk in the Knowledge Economy: Toward Reputable Action, Organization Science, Vol. 16, No. 3 (May - Jun. 2005), pp. 308-322.

30 Dowling, G. (2006), Reputation risk: it is the board's ultimate responsibility, Journal of Business Strategy, 999 Vol. 27 Issue: 2, pp. 59-68.
} 


\subsection{Sustav integriranog upravljanja rizicima}

Integrirano upravljanje rizicima relativno je novi pristup koji se u literaturi pojavio početkom 21. stoljeća (Lam, 2001.; Meulbroek, 2002.; Liebenberg i Hoyt, 2003.; Beasley et al.., 2005.; Nocco i Stulz, 2006.), no njegova šira provedba započela je tek nakon globalne financijske krize (Miloš Sprčić et al., 2016.). Teške posljedice globalne financijske krize rezultirale su preispitivanjem procesa i pristupa upravljanju rizicima. U studijama brojnih relevantnih institucija poput OECD-a (2009.), Banke za međunarodna poravnanja (BIS, 2008.) te Britanske agencije za nadzor financijskih usluga (FSA, 2009.), navedeni su argumenti o neučinkovitosti dosadašnjih sustava upravljanja rizicima, ne samo zbog nedostataka statističko-matematičkih modela procjene rizika i nerealnih pretpostavki modela, već i zbog neodgovarajućih procedura korporativnog upravljanja koji se mogu pripisati tradicionalnom ,silo-based" upravljanju rizicima (Traditional Risk Management - TRM) (OECD, 2009.). U TRM sustavu rizicima se upravlja pojedinačno od strane izvršnih direktora, s malo ili bez komunikacije kako odluke o upravljanju nekim rizikom utječu na izloženost drugim rizicima te ostvarivanje postavljenih ciljeva. Dakle, ne analizira se ukupna rizična izloženost što dovodi do podcijenjenosti utjecaja rizika, krive strategije upravljanja rizicima, a u kriznim vremenima i do znatno većih gubitaka od onih koji su procijenjeni.

Stoga navedene studije i dokumenti predlažu da upravljanje rizicima treba biti „visoko na listi prioriteta svake organizacije“, naglašavajući potrebu za cjelovitim upravljanjem rizicima. Upravo Integrirano upravljanje rizicima (ERM) može odgovoriti suvremenim izazovima upravljanja te predstavlja novu paradigmu koja uključuje identifikaciju, procjenu izloženosti kao i mjere upravljanja svim rizicima koji mogu ugroziti ciljeve - kako onim strateškim, tako i financijskim i operativnim rizicima. U tome smislu, primjenom ERM sustava upravljanja rizicima, na vrijeme se identificiraju i procjenjuju poslovni rizici pa tako među njima i reputacijski rizik. Učinkovito upravljanje reputacijskim rizikom zapravo podrazumijeva pravodobnu identifikaciju drugih čimbenika poslovnih rizika čija realizacija može ugroziti reputaciju kompanije.

Prema konceptu integriranog upravljanja, kompanije bi trebale upravljati svim rizicima cjelovitim i integriranim pristupom, uzimajući u obzir međuovisnosti različitih rizičnih situacija. ERM predstavlja ključnu potporu poslovnoj strategiji kompanije te je neizostavan alat za koordiniranje procesa upravljanja prilikama i prijetnjama s ciljem stvaranja i povećanja vrijednosti kompanije. ${ }^{31}$ Proces integriranog upravljanja rizicima sastoji od nekoliko međusobno povezanih faza (Miloš Sprčić, 2013.; 2014.) koji su prikazani na slici 2. te objašnjeni u nastavku rada.

$31 \quad$ Gatzert, N., Schmit, J. (2016), Supporting strategic success through enterprise-wide reputation risk management, The Journal of Risk Finance, Vol. 17 Issue: 1, pp. 26-45. 
Slika 2. Proces integriranog upravljanja rizicima

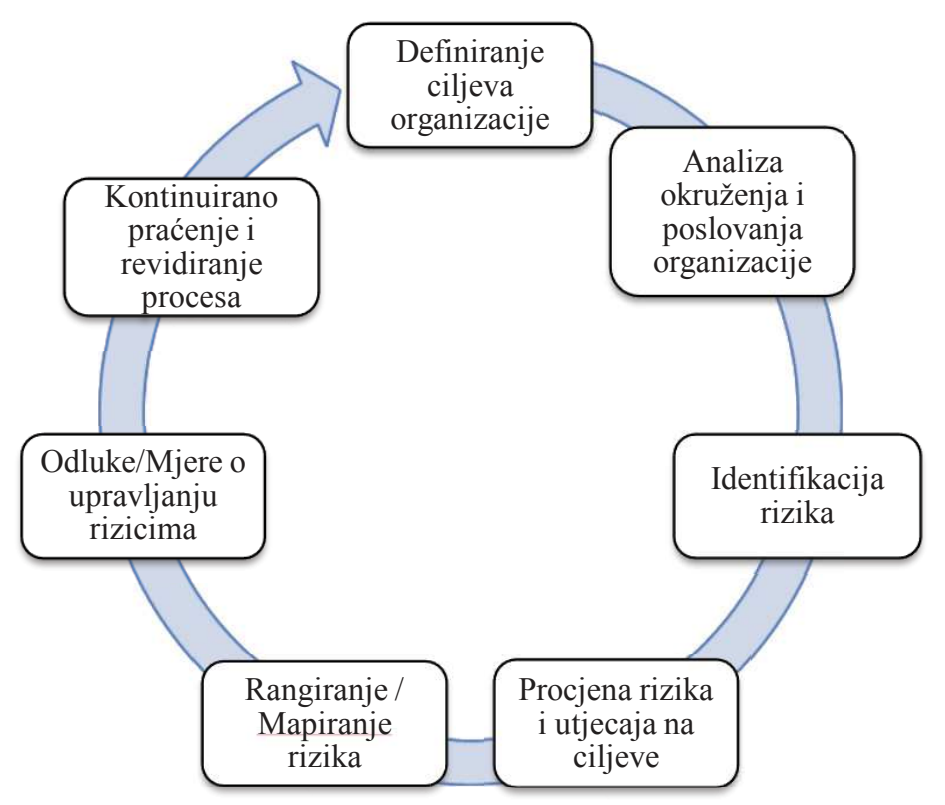

Izvor: prilagođeno prema Miloš Sprčić, Danijela (2014) A New Era of Risk Management - An Integrated Approach to Corporate Risks, Chapter 1 in Miloš Sprčić, Danijela (Edt) (2014) Risk Management: Strategies for Economic Development and Challenges in the Financial System. Nova Science Publishers. Hauppauge, N.Y., pp. 1-28.

1. Definiranje ciljeva organizacije. Ciljevi predstavljaju kriterij koji je pod utjecajem rizika (Meulbroek, 2002.). Zreli i učinkovit ERM sustav treba biti djelotvoran, tj. treba biti povezan sa strateškim menadžmentom i procesom donošenja odluka $u$ kontekstu identifikacije, procjene i upravljanja svim rizicima koji mogu ugroziti postavljene ciljeve organizacije. Bez jasno postavljenih ciljeva i strategije koja vodi do njihovih ostvarenja, ERM sustav ne može učinkovito funkcionirati jer nije jasno koji rizici su relevantni za poslovanje, a koji se mogu zanemariti jer njihov utjecaj nije bitan za organizaciju.

2. Analiza okruženja i poslovanja organizacije. Ova faza pruža informacije na kojima se temelji analiza i kvantitativna obrada različitih vrsta rizika. Razumijevanje makro okruženja, situacije u industriji te konkurentske strategije omogućuje precizniju i objektivniju identifikaciju i procjenu rizika (Stowe, 2002.). Analiza se najčešće provodi uz korištenje strateških alata poput PESTLE analize, Porterovog modela pet konkurentskih sila te SWOT analize.

3. Identifikacija rizika. Identifikacija rizika uključuje određivanje značajnih događaja koji mogu negativno utjecati na sposobnost postizanja strateških planova i ciljeva (Lundqvist, 2014.). Najčešće u njihovoj identifikaciji sudjeluje panel stručnjaka jer bi identifikacija od strane jedne osobe bila previše subjektivna. Stručnjaci iz različitih područja s različitim sposobnostima gledaju na rizike iz različitih perspektiva te stoga mogu identificirati veći broj različitih vrsta rizika u odnosu na pojedinca ili homogene skupine (Meulbroek, 2002.), pri čemu se tehnika Brainstorminga koristi za podupiranje konsenzusa postignutoga putem Delphi metode.

4. Procjena rizika i utjecaja na ciljeve. Procjena rizika predstavlja procjenu stupnja do kojega bi prethodno utvrđeni čimbenici rizika mogli utjecati na ciljeve organizacije. 
Dimenzija na kojoj se temelji ova faza IRM procesa tiče se kvantitativne procjene identificiranih rizika (Lundqvist, 2014.). Rizici su kvantificirani prema njihovoj vjerojatnosti pojavljivanja i značajnosti njihovoga utjecaja na prethodno definirane ciljeve (Shimpi, 2001.), za što stručnjaci razvijaju primjerene skale vjerojatnosti i značajnosti za ciljeve organizacije koje su prilagođene značajkama procjenjivanih organizacija. Procjena značajnosti i vjerojatnosti rizika može uključivati, osim kvalitativnih procjena stručnjaka i različite kvantitativne metode procjene poput analize osjetljivosti, analize scenarija, simulacija, stabla odlučivanja, stabla događaja, analize povijesnih podataka i sl.

5. Rangiranje / Mapiranje rizika važan je dio procesa integriranog upravljanja rizicima. Nakon što se za svaki rizik odredi vjerojatnost i značajnost koristeći primjerene mjere i skale, kreira se dvodimenzionalna mapa rizika koja je podijeljena u četiri kvadranta, gdje se na osi x nalazi vjerojatnost, a na osi y značajnost svakoga rizika. Vizualni prikaz svih rizika na jednome mjestu te procjena njihove međusobne povezanosti i ukupne izloženosti dodatna je vrijednost ERM pristupa. Mapa rizika trebala bi predstavljati okvir strategije integriranog upravljanja rizicima svake organizacije jer pomaže pri donošenju odluke kojim rizicima treba aktivno upravljati, koje rizike treba pratiti, a koji se mogu zanemariti jer nisu niti vjerojatni niti značajni za organizaciju.

6. Odluke / mjere o upravljanju rizicima. Osnovne strategije obuhvaćaju izbjegavanje rizika u slučaju da nema mogućnosti aktivnog upravljanja, smanjenje utjecaja kroz diversifikaciju rizika, prijenos rizika na druge organizacije kupnjom instrumenata zaštite od rizika te pasivno prihvaćanje rizika ako njegov utjecaj odnosno vjerojatnost nastupanja nije veliki.

7. Kontinuirano praćenje i revidiranje procesa. Mapa rizika te odluke o upravljanju koje su donesene temeljem provedenoga ERM procesa dovoljni su za kratkoročno upravljanje rizicima. Obzirom na visoku dinamičnost okruženja iz koje proizlaze promjene ekonomskih, političkih i drugih čimbenika, reevaluacija rizika je nužna barem jednom godišnje jer je na taj način moguće uočiti nove rizike te repozicionirati postojeće.

\subsection{Integracija reputacijskog rizika u proces integriranog upravljanja rizicima}

Jedan od važnih ciljeva ERM sustava jest posvećenost očuvanju reputacije kompanije, prepoznajući reputaciju kao ključni element cjelokupnog upravljanja rizicima. Dok neke kompanije i dalje pokušavaju odvojeno upravljati različitim vrstama rizika koristeći tradicionalni pristup upravljanja rizicima (engl. Traditional „silo-based“ Risk Management, TRM), dolazi do općeg prihvaćanja ideje od strane sve većeg broja organizacija da je integrirani pristup upravljanja rizicima, koji uključuje i reputaciju, sastavni dio poslovne strategije. Upravljanje reputacijskim rizicima ne smije biti prema metodi „silosa“ odnosno odvojeno od drugih poslovnih rizika. Integrirani pristup rizicima također zahtijeva uspostavljanje nezavisnih internih kontrola i interne revizije, kako bi se mogla procijeniti kvaliteta procesa identifikacije, analize i procjene rizika. U nastavku ovoga rada izlaže se prijedlog integracije upravljanja reputacijskim rizikom u proces integriranog upravljanja 
rizicima. Za učinkovito upravljanje reputacijskim rizikom te njegovu integraciju u ERM okvir organizacije, potrebno je donijeti Strategiju rizika na razini organizacije koja obuhvaća reputacijski rizik kao „rizik od rizika“, procijeniti sve strateške, operativne i financijske rizike kojima je organizacija izložena, odrediti vlasnike svih rizika (engl. Risk Owners) ${ }^{32}$ pa tako i reputacijskoga rizika te stvoriti organizacijsku kulturu koja uključuje organizacijsku svijest o definiranoj razini tolerancije rizika i važnosti upravljanja rizicima. ${ }^{33}$

Strategija rizika podrazumijeva uključivanje reputacijskih rizika u određivanje strateških ciljeva kompanije, kao i u postavljanje razine tolerancije rizika. Pri definiranju aktivnosti i procedura ERM-a najvažniji je imperativ koordinacija i usklađivanje sa strateškim ciljevima organizacije. Za definiranje razine tolerancije rizika organizacije u kontekstu reputacijskih rizika preduvjet je mjerenje reputacije i reputacijskih rizika, npr. povezivanjem utjecaja promjene ponašanja interesnih skupina i odabranih mjera financijskih performansi kompanije. Prema njihovim značajkama, iskustvima i ciljevima, organizacije se mogu odlučiti za prihvaćanje različitih razina i vrsta rizika, što znači da procjena svih mogućnosti upravljanja rizicima mora biti temeljena na prethodno definiranoj razini tolerancije rizika koju određuje Uprava kompanije.

Procjena svih rizika obuhvaća identifikaciju, procjenu utjecaja na ciljeve, od kojih je jedan od najvažnijih i očuvanje pozitivne reputacije kompanije, kao i određivanje mjera upravljanja rizicima.

\section{1) Identifikacija rizika}

Za uspješno upravljanje reputacijskim rizicima potrebna je identifikacija potencijalnih kriznih događaja, koja također uzima u obzir činjenicu da je reputacijski rizik ,,rizik od rizi-

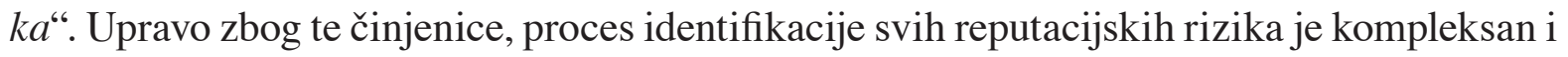
sastoji se od više koraka. Prvi i najvažniji korak je identifikacija temeljnih poslovnih rizika koji su relevantni za reputaciju te razumijevanje načina na koje ti rizici mogu utjecati na reputaciju organizacije odnosno na percepciju o organizaciji kod raznih interesnih skupina. U tom kontekstu bitno je imati u vidu vezu između nastanka nepovoljnog događaja relevantnog za reputaciju organizacije i načina na koji taj događaj mijenja percepciju interesnih skupina. Promjene u percepciji interesnih skupina mogu dovesti do financijskih gubitaka za kompaniju, npr. zbog pada prihoda ili povećanja troška kapitala. Proces identifikacije se mora provesti za sve rizike koji bi mogli biti prisutni u organizaciji, ali i za sve rizike koji bi mogli nastati izvan organizacije, zbog učinka „reputacijskog prelijevanja“ iz industrije ili makrookruženja. U tom kontekstu, druga faza ERM procesa „Analiza okruženja i poslovanja organizacije“ igra važnu ulogu. Ako neki od partnera, dobavljača ili konkurenata iz industrije koristi nemoralne i nelegalne poslovne prakse, negativni reputacijski učinci bi se mogli odraziti i na promatranu organizaciju. Također, promjene u makrookruženju mogu dovesti do prelijevanja reputacijskoga rizika na sva poduzeća u nekoj industriji. Primjer su poduzeća iz duhanske industrije koja su već dulje vrijeme izložena negativnom reputacij-

\footnotetext{
32 Vlasnik rizika je termin koji se koristi u suvremenoj literaturi iz područja upravljanja rizicima. Označava osobu odgovornu za provedbu mjera upravljanja pojedinim kategorijama rizika, a prema strategiji integriranog upravljanja rizicima.

33 Gatzert, N., Schmit, J. (2016), Supporting strategic success through enterprise-wide reputation risk management, The Journal of Risk Finance, Vol. 17 Issue: 1, pp. 26-45.
} 
skome riziku radi općih društveno-kulturnih promjena opće svijesti društva o štetnome utjecaju pušenja na zdravlje, što se negativno odražava na profitne marže svih poduzeća i dovodi do konsolidacije cijele duhanske industrije u kojoj opstaju samo najveći igrači koji poslovanje temelje na ekonomiji obujma.

Ipak, za reputaciju organizacije najpogubniji su događaji vezani uz nepoštenu poslovnu praksu i kriminalne aktivnosti, neetično ponašanje, pravne sukobe i manjkave proizvode. Za uspješno upravljanje reputacijskim rizicima potrebno je anticipirati događaje koji se još nisu dogodili, kao i konstantno promatrati kombinirane učinke promjena u društvenim normama i tehnološkome napretku, što upravo omogućava ERM pristup kroz provedbu PESTLE analize, analize industrije, analize poslovanja te SWOT analize kompanije. Da bi organizacija mogla uspješno identificirati konkretne razloge gubitka reputacije i vezanih financijskih gubitaka, najvažnije je uočiti i analizirati promjene ponašanja različitih interesnih skupina. Na primjer, svaki prelazak kupca kod konkurenta implicira pad prihoda organizacije, dobavljači mogu zatražiti promjene uvjeta odobravanja trgovačkih kredita zbog povećanja kreditnoga rizika, zaposlenici mogu zbog nezadovoljstva uvjetima rada otići iz kompanije, a investitori mogu uslijed povećanja rizičnosti poslovanja organizacije povećati cijenu kapitala. Općenito, može se reći da kompanije koje ne upravljaju svojim poslovnim rizicima moraju platiti veću premiju rizika kako bi zadržale kupce, dobavljače, investitore, ali i zaposlenike, te im na taj način kompenzirati povećani rizik koji snose poslujući s takvom kompanijom. Kao rezultat toga, povećana izloženost poslovnim rizicima, koja se manifestira kroz lošiju percepciju reputacije kompanije od strane svih dionika, povećava opće troškove poslovanja. Kombinacija averzije prema riziku i lošije perspektive poslovanja slabi veze između kompanije i njezinih dionika, čime započinje negativna spirala. Kroz gore navedene argumente, vidljiv je progres od povećanja ukupnoga rizika prema reputacijskome riziku koji vodi do povećanoga rizika stečaja i likvidacije. Čak i ako likvidacija nije izgledna, povećanje reputacijskoga rizika smanjit će vrijednost kompanije za iznos jednak povećanim troškovima održavanja poslovanja u novonastalim uvjetima. Može se zaključiti da je pravi trošak povećane izloženosti reputacijskome riziku upravo smanjenje vrijednosti kompanije uzrokovane lošijim financijskim performansama i slabijom poslovnom perspektivom. ${ }^{34}$

\section{2) Procjena utjecaja na ciljeve}

Mjerenje i procjena reputacijskih rizika započinje ocjenom izvora rizičnosti. U najvećem broju slučajeva su gubici reputacije izazvani nepovoljnim operativnim ili strateškim rizicima koje je vrlo teško kvantificirati. Općenito je za adekvatnu kvantitativnu i kvalitativnu procjenu temeljnih rizika potreban holistički pristup koji uzima u obzir sve potencijalne štete za reputaciju, u slučaju nastanka nepovoljnog događaja. Financijski gubici nastali kao posljedica reputacijski nepovoljnoga događaja se u literaturi uglavnom definiraju kao razlika tržišnih gubitaka prije i poslije nastanka nepovoljnoga događaja. Druge financijske mjere su gubitak prihoda, pad profitabilnosti ili smanjenje tržišnoga udjela. Tu na vidjelo izlazi specifičnost mjerenja reputacijskih rizika, jer se ne mjere direktno promjene percepcije kod interesnih skupina, već se pokušava uočiti njihov indirektni učinak na financijske

\footnotetext{
$34 \quad$ Shapiro, A. C. and S. Titman (1998), An Integrated Approach to Corporate Risk Management, Stern, J. M. and D. H. Chew Jr., eds., The revolution in corporate finance, Third edition. Malden, Mass. and Oxford: Blackwell Business, pp. 251-265.
} 
rezultate organizacije. Dodatno, neki reputacijski nepovoljan događaj ne mora odmah imati neposredan utjecaj na profit, ali može formirati bazu za buduće promjene u percepcijama koje mogu imati razorne posljedice na dugoročne rezultate organizacije.

\section{3) Određivanje mjera upravljanja rizicima}

Nakon mjerenja potencijalnih ishoda reputacijskih rizika moraju se donijeti odluke o tretmanu rizika. Sukladno šestom koraku ERM procesa „Odluke/mjere o upravljanju rizicima" moguće je na nekoliko načina upravljati reputacijskim rizikom. Izbjegavanje rizika je strategija potpune eliminacije potencijalnoga rizičnog događaja. Da bi postiglo potpuno izbjegavanje rizika, organizacija se mora odreći i svih potencijalnih dobrobiti koje izlaganje tom riziku donos, te bi se zbog toga ta strategija trebala smatrati krajnjim rješenjem upotrijebljenim tek nakon što se iskoriste sve druge opcije. S druge strane, mjere smanjenja utjecaja rizika koriste se za smanjenje vjerojatnosti nastanka i snage utjecaja potencijalnoga reputacijski nepovoljnog događaja. Zbog specifičnosti reputacijskih rizika moguće je razlikovati mjere koje se provode prije i nakon nastanka reputacijski nepovoljnoga događaja. Preventivne mjer, odnosno mjere koje se provode prije nastanka štetnog događaja, u srži su modela upravljanja reputacijskim rizikom kroz ERM proces. Ako u fazi procesa procjene svih poslovnih rizika organizacija uoči da postoje poslovni rizici koji mogu rezultirati ozbiljnom štetom za reputaciju, onda su to rizici visokog prioriteta kojima se treba aktivno upravljati primjenom odgovarajućih mjera za taj tip rizika.

U slučaju da je reputacijski nepovoljan događaj ipak nastao, ključno je predvidjeti reakcije pripadnika različitih interesnih skupina na taj događaj. Za reputaciju su od vitalne važnosti krizne komunikacijske strategije usmjerene prema interesnim skupinama, jer mogu značajno utjecati na obujam štete za reputaciju. ${ }^{35}$ Plan odgovora na krizu bi, prema tome, trebao uključivati plan kriznog komuniciranja prema svakoj od ključnih interesnih skupina. Prema Gatzert i Schmit (2016. ${ }^{36}$ postoji nekoliko strategija za različite ciljane interesne skupine. Ključne identificirane akcije usmjerene prema investitorima su poboljšanje upravljanja organizacijom, otpuštanje uprave, poboljšanje sustava internih kontrola, reorganizacija poslovanja ili otkup vlastitih dionica. S druge strane, akcije prema klijentima i kupcima su marketinške kampanje, ,rebranding“ i eksterna validacija kvalitete proizvoda od strane nezavisnih ispitivača. Na kraju, akcije usmjerene prema zaposlenicima uključuju uvođenje sustava priznanja i nagrada te ulaganje u edukaciju i trening zaposlenika kako bi poboljšali integritet organizacije i očuvali vjernost zaposlenika. Ovaj rad ne obuhvaća strategije kriznog menadžmenta već se usmjerava na pravodoeno identificiranje i upravljanje poslovnim rizicima s ciljem sprječavanja njihovoga nastanka i negativnoga utjecaja na reputaciju organizacije. Moguća je i strategija transfera reputacijskog rizika na druge organizacije poput osiguravajućih društava. Ipak, treba napomenuti da su police osiguranja koje u sebi imaju uključene reputacijske rizike vrlo kratko na tržištu i još uvijek se smatraju inovacijom tržišta osiguranja te uglavnom pokrivaju mjere krizne komunikacije. Osiguranje stvarnih financijskih gubitaka, npr. pada prihoda uzrokovanoga reputacijskim rizicima $\mathrm{z}$ sada nije dostupno. Kao zadnji i vrlo važan korak procesa upravljanja rizicima nameće se

\footnotetext{
35 Rayner, Jenny (2003) Managing reputational risk: curbing threats, leveraging opportunities. IIA Risk Management Series, West Sussex: John Wiley \& Sons 1td., str. 89.

36 Gatzert, N., Schmit, J. (2016), Supporting strategic success through enterprise-wide reputation risk management, The Journal of Risk Finance, Vol. 17 Issue: 1, pp. 26-45.
} 
redovito i proaktivno nadziranje reputacijskih rizika. Uslijed ubrzanih promjena okruženja i važnosti reputacije, pogotovo za nove organizacije, bitno je redovito ažurirati sve dostupne informacije o identificiranim rizicima relevantnim za reputaciju organizacije. Dodatnu važnost nadzoru reputacijskih rizika daje i nagli porast učinkovitosti komunikacijskih tehnologija te razvoj društvenih mreža, koje mogu imati značajan utjecaj na reputaciju kompanije.

Upravljanje rizicima treba se sastojati od jasno definirane podjele uloga i odgovornosti, s naglaskom na definiranju vlasnika pojedinih rizika (engl. Risk Owner). Osobe kojima se povjeri upravljanje nekim od identificiranih rizika moraju imati široki spektar organizacijskih znanja, ali i bogato iskustvo te sposobnost upravljanja ljudima i procesima. Tako osoba koja je imenovana vlasnikom reputacijskoga rizika mora biti odgovorna za izgradnju poslovne reputacije, upravljanje posljedicama kriza i skandala te za definiranje i provođenje strategije očuvanja reputacije organizacije, no također mora jako dobro razumjeti sve ostale poslovne rizike kojima je kompanije izložena te biti aktivno uključena u ERM proces kako bi doprinijela procjeni utjecaja pojedinih rizika na reputaciju kompanije. Na taj način se reputacijski rizici na vrijeme anticipiraju te kroz određene mjere upravljanja i preveniraju. U slučaju da ipak dođe do nastupa događaja koji ima negativne posljedice na reputaciju tada je najvažnija eksterna komunikacija i učinkovita reakcija tima za upravljanje kriznim situacijama kako bi posljedice bile što manje, a gubitak reputacije neznatan ili tek privremen.

Kako bi se uspješno upravljalo reputacijskim rizikom, važno je da reputacija postane dijelom kulture rizika. Kultura rizika uključuje organizacijsku svijest o definiranoj razini tolerancije rizika. Kao dio korporativne kulture, primjerena kultura rizika osigurava opću osviještenost o rizicima kroz cijelu organizaciju te učinkovitije omogućava donošenja poslovnih odluka u uvjetima rizika i neizvjesnosti. Uloge i odgovornosti snošenja rizika moraju biti definirane kroz cijelu organizacijsku strukturu, počevši od vrhovnoga i izvršnoga menadžmenta, pa prema svakome zaposleniku organizacije. Kultura rizika utemeljuje bazu temeljeu koje se rizici identificiraju, analiziraju i kontroliraju. Za uspostavljanje primjerene kulture rizika potreban je kontinuiran i temeljit angažman uprave, ali i učinkovita komunikacija prema svim zaposlenicima. Jasna podrška menadžmenta empirijski je dokazana kao jedna od važnih odrednica zrelosti i učinkovitosti ERM sustava. ${ }^{37}$ Mnoge napredne kompanije uvode edukacije i treninge na temu poslovnih rizika, kako bi educirale svoje zaposlenike o važnosti različitih aspekata rizika, ali i kako bi ih naučile prepoznati potencijalne rizike koji bi mogli proizaći u njihovim svakodnevnim aktivnostima.

\section{ZAKLJUČAK}

Reputaciju danas možemo promatrati kao indikator uspješnosti organizacij, odnosno sponu između realizacije ciljeva organizacije te zadovoljavanja interesa njenih ključnih dionika. Ona se krije duboko u percepcijama klijenata, partnera, dobavljača, investitora, zaposlenika i drugih interesnih skupina organizacije. Organizacije s pozitivnom reputacijom postižu značajne konkurentske prednosti i učinkovitije su od konkurenata lošije repu-

37 Miloš Sprčić, Danijela; Kožul, Antonija; Pecina, Ena (2017) Managers' Support - A Key Driver behind Enterprise Risk Management Maturity, Zagreb international review of economics \& business. 20, Special Conference Issue; 25-39. 
tacije. Reputacija je značajan i vitalan čimbenik uspjeha svih organizacija, no zbog svoje potencijalne izloženosti velikom broju nepovoljnih događaja vrlo je krhka i varijabilna. Ta varijabilnost je dodatno pojačana današnjom širokom dostupnošću informacija, stalnom prisutnošću medija i povećanom svijesti društva. Zbog toga je bitno na vrijeme anticipirati te analizirati na koji način različiti nepovoljni događaji iz eksternog i internog okruženja organizacije mogu kreirati reputacijski rizik. Upravo zbog visoke razine utjecaja nepovoljnih događaja na reputaciju, u ovome radu se naglašava značaj njihovoga „unaprednog““ identificiranja te učinkovitoga upravljanja čimbenicima reputacijskoga rizika. Jednom kada nepovoljni događaji nastupe, tada više ne govorimo o upravljanju rizicima već o kriznome menadžmentu, području koje nije tema ovoga rada.

Reputacijski rizik je ,,rizik od rizika“ koji nastaje kao posljedica različitih vrsta strateških, operativnih i financijskih rizika kojima su izložene sve organizacije, na način da se gubitak dobrog imen, odnosno reputacije transformira u smanjenje prihoda, povećanje troškova odnosno pad broja kupaca te posljedično u pad tržišnoga udjela te smanjenje proizvodnje. Sve navedene transformacije reputacijskoga rizika imaju negativan učinak na financijsku uspješnost i produktivnost kompanije. Da bi takve ishode učinkovito spriječil, odnosno barem smanjile vjerojatnost njihovog nastupanja i značajnost za poslovne ciljeve, nužno je da kompanije proaktivno upravljaju svim rizicima kojima su izložene. Zbog toga se u ovome radu analizira i zagovara koncept integriranoga upravljanja rizicima kao jedino dugoročno rješenje koje obuhvaća i učinkovito upravljanje reputacijskim rizikom. Integracija reputacijskoga rizika u identifikaciju, procjenu, upravljanje i kulturu rizika omogućava kontinuirani i sveobuhvatan nadzor nad potencijalnim nepovoljnim događajima koji mogu ugroziti reputaciju organizacije. Odgovornost uprave je da odredi strateške smjernice cjelokupne organizacije, a na svim ostalim zaposlenicima je da, slijedeći strategiju uprave, štite organizaciju od reputacijskih rizika.

\section{LITERATURA:}

1. Alsop, R. J., (2004), Corporate reputation: Anything but superficial - the deep but fragile nature of corporate reputation, Journal of Business Strategy, Vol. 25, Issue 6, pp. 21-29.

2. Bank for International Settlement (BIS) (2008). Principles for sound liquidity risk management. Basel.

3. Basel Committee (2009), Enhancements to the Basel II Framework, Basel, dostupno na: www.bis.org/publ/bcbs157.pdf (pristupano 25. 8. 2017.).

4. Beasley, M. S., Clune, R, \& Hermanson, D. R. (2005). Enterprise Risk Management: An Empirical Analysis of Factors Associated with the Extent of Implementation. Journal of Accounting and Public Policy, 24, pp. 521-531.

5. Culp, L. C. (2002), The Art of Risk Management, John Wiley \& Sons.

6. Dowling, G. (2006), Reputation risk: it is the board's ultimate responsibility, Journal of Business Strategy, Vol. 27, Issue 2, pp. 59-68.

7. Eckert, C. (2017), Corporate reputation and reputation risk: Definition and measurement from a risk management perspective, The Journal of Risk Finance, Vol. 18, Issue 2, pp. 145-158. 
8. Financial Service Authority (FSA) (2008). Strenghtening liquidity standards. London.

9. Firestein, P. J. (2006), Building and protecting corporate reputation, Strategy \& Leadership, Vol. 34, Issue 4, pp. 25-31.

10. Fombrun, C., van Riel, C. (1997), The reputational landscape: a convergence of research and practice, Corporate Reputation Review, Vol. 1, No 1/2, pp. 1-16.

11. Gatzert, N., Schmit, J. (2016), Supporting strategic success through enterprise-wide reputation risk management, The Journal of Risk Finance, Vol. 17, Issue 1, pp. 26-45.

12. Gotsi, M., Wilson, A. M. (2001), Corporate reputation: seeking a definition, Corporate Communications: An International Journal, Vol. 6 Issue: 1, pp. 24-30.

13. Hirsch, P. B, (2015), Sacred cows and the known unknowns, Journal of Business Strategy, Vol. 36 Issue: 6, pp. 54-58.

14. Hutt, R. W. (2016), Reputation on the line: the Starbucks cases, Journal of Business Strategy, Vol. 37, Issue 1, pp. 19-26.

15. Lam, J. (2001). The CRO is here to stay. Risk Management, 48, pp. 16-20.

16. Larkin, J, (2003), Strategic Reputation Risk Management, Palgrave Macmillan, New York.

17. Liebenberg, A. P., \& Hoyt, R. E. (2003). The Determinants of Enterprise Risk Management: Evidence from the Appointment of Chief Risk Officers. Risk Management and Insurance Review, Vol. 6, Issue 1, pp. 37-52.

18. Louisot J. P., Gaultier-Gaillard, S, (2006), Risks to Reputation: A Global Approach, The Geneva Papers 2006, 31, (425-445).

19. Lundqvist, S. A. (2014). An exploratory study of enterprise risk management: pillars of ERM. Journal of Accounting, Auditing \& Finance, Vol. 29, Issue 3, pp. 393-429.

20. Meulbroek, L. K. (2002). Integrated Risk Management for the Firm: A Senior Manager's Guide. Journal of Applied Corporate Finance, Vol. 14, pp. 56-70.

21. Miloš Sprčić, Danijela (2013.), Upravljanje rizicima - temeljni koncepti, strategije $i$ instrumenti, Sinergija.

22. Miloš Sprčić, Danijela (2014) A New Era of Risk Management - An Integrated Approach to Corporate Risks, Chapter 1 in Miloš Sprčić, Danijela (Edt) (2014) Risk Management: Strategies for Economic Development and Challenges in the Financial System. Nova Science Publishers. Hauppauge, N.Y., pp. 1-28.

23. Miloš Sprčić, Danijela, Marina Mešin, Željko Šević, Mojca Marc (2016) Does enterprise risk management influence market value - A long-term perspective, Risk Management, Vol 18, Issue 2, pp. 65-88.

24. Miloš Sprčić, Danijela; Bandula, Martina (2010), Utjecaj aktivnosti odnosa s investitorima na trošak kapitala i prognoze financijskih analitičara // Proceedings of the 2nd International Conference "Vallis Aurea" focus on: Regional Development / prof. dr. sc. Branko Katalinić (ur.) Požeg : Polytehnic of Požega, Croatia \& DAAAM International Vienna, Austria, pp. 911-922.

25. Miloš Sprčić, Danijela; Kožul, Antonija; Pecina, Ena (2017) Managers' Support - A Key Driver behind Enterprise Risk Management Maturity, Zagreb international review of economics \& business. 20, Special Conference Issue; pp. 25-39. 
26. Murray, K. (2004), Reputation - Managing the single greatest risk facing business today, Journal of Communication Management, Vol. 8, Issue 2, pp. 142-149.

27. Nocco, B. W, \& Stulz, R. M. (2006). Enterprise Risk Management: Theory and Practice. Journal of Applied Corporate Finance, Vol. 18, Issue 4, pp. 8-20.

28. OECD, (June 2009). Corporate Governance and the Financial Crisis: Key Findings and Main Messages. Paris OECD. Available at: http://www.oecd.org/corporate/ca/ corporategovernanceprinciples/43056196.pdf.

29. Rayner, Jenny (2003) Managing reputational risk: curbing threats, leveraging opportunities. IIA Risk Management Series, West Sussex: John Wiley \& Sons ltd.

30. Resnick, J. T. (2004), Corporate reputation: Managing corporate reputation - applying rigorous measures to a key asset, Journal of Business Strategy, Vol. 25 Issue: 6, pp. 30-38.

31. Ryan, T. M. i Jacobs, C. A. (2004) Using Investor Relations to Maximize Equity Valuation. Wiley finance series.

32. Scott, S. V., Walsham, G. (2005), Reconceptualizing and Managing Reputation Risk in the Knowledge Economy: Toward Reputable Action, Organization Science, Vol. 16, No. 3 (May - Jun., 2005), pp. 308-322.

33. Shapiro, A. C. and S. Titman (1998), An Integrated Approach to Corporate Risk Management, Stern, J. M. and D. H. Chew Jr., eds., The revolution in corporate finance, Third edition. Malden, Mass. and Oxford: Blackwell Business, pp. 251-265.

34. Shimpi, P. (1999). Integrating Corporate Risk Management. Texere.

35. Stowe, D. John et al. (2002). Analysis of Equity Investments - Valuation. United Book Press, Baltimore.

36. United States Federal Reserve Board (1997), Framework for risk-focused supervision of large Complex institutions, dostupno na: www.federalreserve.gov/boarddocs/srletters/1997/sr9724a1.pdf.

37. Walter, I. (2013), The value of reputational capital and risk in banking and finance, Banking, Accounting and Finance, Vol. 5, Nos. 1/2, 2013. 